\title{
Abortion, embryo destruction and the future of value argument
}

\section{J Savulescu}

A bortion and embryo destruction prevent a future of value, but that does not make them wrong.

Abortion involves the killing of a fetus. One bad thing about killing a fetus is that the fetus is deprived of a future of value. Think of all the things which make your life good and worth living: understanding the world, seeing your children grow into independent, intelligent, and happy people, watching a sunset over the hills, enjoying good times with friends. By killing the fetus, we are depriving it of a future life likely to contain these things. And more. The fetus would likely grow to be a person who would have contributed to the world in many ways-bringing joy to its parents, happiness, and friendship to many. That person would have laboured for society and perhaps even discovered a cure for cancer or developed the first bionic eye.

The loss of these possible futures is bad. It makes the killing of a fetus wrong. This is Don Marquis's argument against abortion. ${ }^{1}$ It is one of the best arguments against abortion which does not rest on theological premises.

Another way of putting this is to say that we have a good reason not to kill a fetus. A (normative) reason for acting is a fact or circumstance forming a sufficient justification for an action. Or in this case, not to perform an action. We have all sorts of reasons for action. Our reasons often conflict. I may have a good reason to visit my mother and a good reason to take my children to the park. What we have most reason to do (after weighing all the conflicting reasons) is what it is right to do. It is what we should do. If we have most reason not to perform an act, it would be wrong (all things considered) to perform that act.

How strong is the reason not to have an abortion? Many entities have a future of value. Most animals have a future of value. Thus, we have good reason not to kill them. This is plausible (though in complete contradiction to the way we treat them). Most people think we have good reason not to destroy animals and that killing them is different from destroying a stone. (But note that few people think we have as much reason not to kill a non-human animal as we have not to kill a person. I will return to this.)
Inanimate objects also have a future of value. Consider a great artist who begins an important work. He has an inspiration at the peak of his career. In a fit of pique, he burns the canvas. (The author Gogol did something like this with part of his greatest work, Dead Souls.) He would have produced a masterpiece. The destruction of such a painting is bad. It deprives the world of a work of art which would have bought pleasure, and been the focus of discussion and inspiration. Some people, such as G E Moore, have even believed that works of art have an intrinsic value.

The artist who destroys a great painting may be doing what he has good reason not to do. If there were no countervailing reason to do what he did, he would be acting wrongly. Indeed, the artist who has an idea of a great painting but fails to take steps to bring it to reality acts wrongly.

But how strong is the reason to paint a great painting? This depends on why the artist failed to realise a future of value. If the artist is lazy, or unable to control his irrational and spontaneous fits of anger, then he acts wrongly, all things considered. He should have completed the painting. If he destroys the painting because he lives in a repressive regime and his paintings are political, and his life is in danger, then he has a good reason to destroy it. He does not act wrongly, all things considered. If he fails to paint a great painting because he chooses to care for his children, he is not acting wrongly, all things considered.

We have good reason not to deprive the world and the people in it of a future of value. The fetus is like a work of art. To destroy a fetus which would have a future of value can be wrong. But whether it is wrong depends on whether there are other good reasons, stronger reasons, to destroy it.

On a future of value argument, killing a fetus is like failing to conceive a baby one could conceive. Consider the following example involving embryo creation and destruction-the issues are the same as abortion in this argument. John and Betty are infertile. They have in vitro fertilisation (IVF). They produce an embryo. The embryo is about to be implanted when John and Betty change their mind. They decide they don't want to have children. The embryo is destroyed. Sam and Edwina are infertile. Edwina produces an egg. Sam produces some sperm. Doctors extract a single sperm for the purposes of ICSI (intracytoplasmic sperm injection), the preferred method of IVF. Just as they are about to inject the sperm, Sam and Edwina interrupt them and tell them they have changed their minds. They don't want children. The sperm and egg are destroyed.

In both cases, the world and the people in it have been deprived of a valuable future. So, too, is the future entity who could have enjoyed that life. Indeed, the egg and sperm have been deprived of a valuable future in just the same way as the embryo. Is a particular sperm and an egg prior to fertilisation different from a sperm and an egg after fertilisation? Not for the purposes of the future of value argument. The fact that the DNA is arranged differently in the case of the embryo is of no moral significance. What we have in both the case of John/Betty and Sam/Edwina is some biological material that could give rise to a future of value. A future of value to the being in the future experiencing it and to other people. In neither case does the entity experience anything prior to or at the time of its destruction-it is merely the possible biological antecedent to something in the future of value.

Some people believe embryos have a different moral significance from gametes. They believe that destruction of an embryo is worse than the destruction of a sperm and an egg. But they are equally precursors to the entity of moral significance. I am equally grateful that my father chose not to (or did choose to-I never asked him) masturbate on the day prior to conceiving me as I am that my parents chose not to abort me. In either case, if either of them had acted differently, I would not have existed (though in the former case another different person may have existed in my place). In each case, genetic material was provided which was necessary for my existence. That is all that is relevant to me as a unique individual.

Each sperm ejaculate contains many millions of sperm. There are clearly incalculable futures of value. Partly for this reason, Judaism makes a sin of Onanism, or masturbation. ${ }^{2}$ Indeed, when we consider that nearly every cell in our body could become a person with the cloning procedure used in Dolly the sheep, the number of potential futures of value is astronomical.

To some, this seems a reductio ad absurdum of the future of value argument. How can we have reason to try to realise so many possible lives? How could it be wrong that so many seeds never produce the beautiful flower that would be a person? 
None the less, I believe we have a good reason to conceive a baby, other things being equal, in the same way as we have a good reason to paint a great painting (even though there are very many great paintings a painter could produce). But whether we have an all things considered obligation to conceive more children depends on what the alternatives are and the impact of these alternatives on our lives and the lives of others. It depends on what else we have good reason to do and the relative strength of these reasons. For example, a person is not under an obligation to conceive a child when that person has many other children who need care, and another child would detract from their care. And a person is not under an obligation to conceive children if it would be harmful to her life or stop her achieving other worthwhile things. But in certain circumstances, when a person does not have better courses of action open, and has sufficient material and emotional supports, conceiving children can be the best thing that person can do. A person can have most reason to have a child.

(Is this too demanding? Ethics, as I see it, is about identifying what we have good reason to do. In many instances we have reason to act in several different, mutually exclusive ways. But that does not imply that we have no reason to act or that it does not matter at all what we do. And freedom to do what we have reason not to do is important. But that should not stifle discussion about our reasons for action. Ethics is not about carte blanche but about identifying what is good. The worth of a future child's life grounds at least some reason to act.)

Even granting there is a reason to realise futures of value, however, generally the strength of the reason to bring a new life into the world is not sufficient to create an obligation to carry a particular pregnancy or conceive a particular child. The reason for this is that having an unwanted child can have a massively detrimental effect on the lives of its parents. This is a significant moral consideration. Moreover, in many cases, the birth of that child will cause the person to give up or reduce other worthwhile activities, such as work. This is also bad.

Most importantly, people in the Western world will (and indeed should) only have a fixed number of children, usually two or three. We don't believe that couples should have to have as many children as they physically can, say 20 . Given limitation of family size is reasonable, it does not matter which potential futures of value a couple choose to realise. That is, if it is reasonable for a couple to limit their family size to three children, it does not matter which three children that couple choose to bear, provided that the children can be expected to have a reasonable prospect of a reasonable life (on the information available). Imagine a 23-year-old girl falls pregnant. She has no difficulty getting pregnant and has no history of genetic disease. She could carry this child or have another different child in a year's time. In the absence of information about some congenital abnormality in one, there is no reason to prefer this child over the one she could have in a year.

How does this relate to the BrownMarquis debate $?^{3-7}$ Marquis claims:

Killing is wrong because it deprives an entity of a future of value.

Brown claims:

Killing is wrong because it deprives a self-conscious being of a self-represented future of value.

Brown's claim could be generalised to:

Killing is wrong because it has property $\mathrm{p}$, where property $\mathrm{p}$ is the property which pertains to killing persons but not to embryos or fetuses.

There have been many versions of this argument. Michael Tooley ${ }^{8}$ and Peter Singer ${ }^{9}$ famously argue that:

Killing is wrong because it frustrates the desire to live of a self-conscious being.

This would make killing you or me different from killing a fetus or an embryo.

Brown believes there is a property p.

Marquis is right that there is a property of killing that pertains both to fetuses and adult humans (the deprivation of a future of value). And that grounds a good reason not to kill. But this property is not unique to human beings. It pertains to all animals and indeed to the destruction of some inanimate objects of value. It is one reason to balance against other reasons.

Marquis is right to draw attention to one aspect of the wrongness of killing but he assumes that this is the only relevant aspect. There is another property of killing which only killing persons has. This generates strong reasons for action and generally strong moral obligations. Fetuses do not have this property. Brown claims this property is the selfrepresented future of value which selfconscious beings have. Singer and Tooley claim it is the frustration for a desire to live of a self-conscious being. We need not settle on what $\mathrm{p}$ is. Property p surely exists. It is more wrong, vastly more wrong, to kill a person than to destroy a painting, or destroy an egg and sperm, or a skin cell that could become a person, or an embryo or even a fetus.

Marquis might respond that animals and pieces of art do have futures of value, but the future of value of human beings is distinctive. And the fetus's future of value is qualitatively and quantitatively similar to or more valuable than the adult human being's future of value. That is what makes killing a fetus as wrong as killing a child or an adult. The loss of what is good in the fetus's life is at least equal to the loss a child experiences by being killed.

The same can be said, however, of a sperm and an egg, a skin cell, and any construction-natural or artificial-of DNA capable of becoming a person. It has a future of value, or at least a possible future of value (only one fifth of embryos make it to being a baby). It is absurd to suggest we have the same reason to protect a sperm and an egg, or a skin cell as we have to protect a child or an adult, just because there is a possible future of value. We may have some reason, but it is not the kind of entity to whom we have strong moral obligations simply because there is a possible future of value.

There is a difference between killing or destroying something and preventing something from coming into existence. Preventing something coming into existence denies a future of value, as does destruction. But they are not the same.

A lump of clay may become a beautiful statue. But destroying a lump of clay is not destroying a statue-it is preventing a statue from coming into existence. Indeed, given the ubiquity of clay, the loss of the clay is hardly significant. An artist could easily obtain some more. What matters more is the particular work of art any lump of clay becomes.

What do I believe property $\mathrm{p}$ is? We can answer this by asking: when did we begin to exist? Jeff McMahan has given a sound answer to this question. ${ }^{10} \mathrm{~A}$ commonsense way of answering this is to ask: when do we cease to exist? Death is defined currently in terms of brain death. Indeed, courts have sanctioned the withdrawal of life-prolonging medical treatment in cases in which a human being is permanently unconscious. ${ }^{11}$ Many people believe we cease to exist in an important biographical sense when our brain ceases to function. Yet our body may live on. That is why we can take organs and tissues from brain dead people for transplantation.

If we cease to exist when our brain dies, we only begin to exist when our brains start to function. Consciousness does not begin until after 20 weeks' gestation. ${ }^{12} 13$ Thus we do not begin to exist as persons, as morally relevant entities, until at least 20 weeks of fetal gestation. The question of when and if killing occurs does not even arise until at least 20 weeks' gestation. ${ }^{10}$

On this account, killing a fetus before 20 weeks is not killing a person, it is preventing a person coming into existence. 
Abortion before 20 weeks is like contraception. It is no different from discarding a sperm and an egg, or an embryo, or a skin cell. Preventing a person from coming into existence does prevent a future of value, but it is not the same as killing. Destroying a lump of clay is not the same as destroying a fine statue. Destroying one of Rodin's statues and destroying one of the lumps of clay in his studio both deprive the world of a future of value. But destroying the statue is worse than destroying the lump of clay.

The Marquis-Brown debate has been important for at least two reasons. Firstly, Marquis's argument is one of the most robust and plausible arguments against abortion. This debate has clarified several points of difference between Marquis and those like Brown who support abortion. These arguments are of great practical consequence. Embryonic stem cell research is one of the most important public issues facing us. Marquis's argument is one of the most plausible arguments that would establish that embryo destruction is wrong.

In sum, Marquis establishes an argument that there are reasons against having an abortion (and by extension to contraception and embryo research). But that argument is defeasible. It is an argument that identifies one important property associated with killing fetuses or embryos. But it does not establish that either abortion or embryo destruction is wrong, all things considered. There are other important considerations that outweigh our obligation not to destroy embryos or fetuses. In the case of embryonic stem cell research, the enormous potential to save people's lives and to improve their quality of life outweighs the wrong of the destruction of some embryos.

\section{ACKNOWLEDGEMENTS}

Ken Boyd, Tony Coady, Hilary Madder, Merle Spriggs, and Agnes Bankier.

J Med Ethics 2002;28:133-135

\section{Author's affiliation}

J Savulescu, Editor. Murdoch Children's Research Institute \& Centre for the Study of Health \& Society, University of Melbourne, Australia; savulesj@cryptic-rch.unimelb.ed.au

\section{REFERENCES}

1 Marquis $\mathbf{D}$. Why abortion is immoral. The Journal of Philosophy 1989;86: 183-202.
2 Judaism has the principle of "Puru Urvu"- "Go forth and multiply." Holy Bible. Genesis viii, 17 states that after exiting from the ark, God said to Noah and his family, and the animals, "they may swarm the earth and be fruifful and multiply".

3 Brown $\mathbf{M}$. The morality of abortion and the deprivation of futures. Journal of Medical Ethics 2000;26: 103-7.

4 Marquis D. Deprivations, futures and the wrongness of killing. Journal of Medical Ethics 2001;27:363-9.

5 Brown $M$. The morality of abortion and the deprivation of futures. Journal of Medical Ethics 2002;28:192-5.

6 Marquis D. A defence of the potential future of value theory. Journal of Medical Ethics 2002;28:198-201.

7 Brown $M$. Abortion and the value of the future: Reply to: A defense of the potential future of value theory. Journal of Medical Ethics 2002;28:202.

8 Tooley M. Abortion and infanticide. Oxford: Oxford University Press, 1983.

9 Singer P. Practical ethics. New York: Cambridge University Press, 1993.

10 McMahan J. Cloning, killing, and identity. Journal of Medical Ethics 1999:25:77-86. 11 Airedale NHS Trust $v$ Bland [1993] 1 All ER 821.

12 Anand KJS, Hickey PR. Pain and its effects in the human neonate and fetus. New England Journal of Medicine 1987;317:1321-9.

13 Royal College of Obstetricians and Gynaecologists' working party. Fetal awareness. London: Royal College of Obstetricians and Gynaecologists, 1997.

\section{Cadaveric organ donation: call for papers}

The Journal of Medical Ethics is planning to publish a series of papers on cadaveric organ donation in the December 2002 issue.

Anyone interested in writing on this subject should send a short outline of their proposed paper to the Editor, Julian Savulescu, at: savulesj@cryptic.rch.unimelb.edu.au

Instructions to authors are available online at www.jmedethics.com/misc/ifora.shtml 